\title{
Polarized Facebook Discourse on Anglophone Nationalism in Cameroon
}

\section{Herbert Rostand Ngouo*}

Department of Bilingual Letters University of Maroua, Cameroon

\begin{tabular}{|c|c|c|c|}
\hline Received: 01.11.2020 & Accepted: 20.11 .2020 & Published: 31.12 .2020 & Final Version: 31.12 .2020 \\
\hline
\end{tabular}

\begin{abstract}
Technological advances have decentralized public communication through networked digital communication. The present paper seeks to critically analyze Facebook contradictory discourses and conversations on the future of the English-speaking regions of Cameroon. In November 2016, the Anglophone population engaged in civil disobedience against the Government of Cameroon over nonchalant attitude towards its predicament or refusal to address its grievances. Focus is on trolls and polarized conversations and discourses made by Anglophone activists on Facebook regarding the socio-political crisis troubling Cameroon since the end of the year 2016. Using Critical Discourse Analysis (CDA) as a methodological and theoretical approach, this study shows that there are two opposing views on Facebook: the separatists' and the pro-unionists' positions. On the one hand, the separatist activists through their Facebook posts discourse repudiate the pan-Cameroonian identity which they associate with francophonisation and cultural assimilation, and promote a separate Anglophone nationalism. On the other hand, the pro-unity Anglophone activists defend national unity and reject the secessionist discourse, thereby reproducing and expressing their adherence to the Pan-Cameroonian identity. This study will try to go beyond linguistic elements analysis to include a systematic construction of the historical and political, sociological and/or psychological dimension in the analysis and interpretation of specific texts/discourse.
\end{abstract}

Keywords: Critical discourse analysis, Facebook, nationalism, La République du Cameroon, Southern Cameroons, one united Cameroon, Ambazonia (Ambazonians)

\section{Introduction}

Since November 2016, the Republic of Cameroon has been going through a crisis that was ignited by socio-political dissatisfaction. The ongoing insurgency began with street manifestations and protests by Anglophone lawyers and teachers. Unions slipped into secessionist's propaganda, civil disobedience, school boycott, arson, etc. The socio-political situation of Cameroon is not an isolated case. Secessionist propensities and nationalist movements are resurfacing around the world today. According to EFA (2014) in Bieri (2014), separatist movements are also prominent even within the European Union, which now has over 40 separatist parties. The most notable of these movements include Scotland in the United Kingdom, Catalonia and the Basque Country in Spain, and Flanders in Belgium (Bieri, 2014, p. 1). In other parts of the world, secession propensities have shaken the foundations of established states like Cameroon's neighbour, Nigeria. This federal state has been grappling with the Biafra secessionist movement since the late 1960s.

\footnotetext{
* Corresponding Author: rostandngouo2000@yahoo.fr
} 
Eritrea broke away from Ethiopia, South Sudan from Sudan. The Kurds in Turkey and in Syria organised a referendum in relation to their national identity in 2017. The longstanding tension between the Quebec Province and Canada is another proof that the established world order has not reached the stable point.

At the beginning of the ongoing crisis situation, almost the entire Anglophone population agreed that there was an Anglophone problem in Cameroon. Following schools and court boycott by Anglophone teachers and lawyers, the Cameroonian Central Government started negotiations with the trade unions and the civil society consortium, and made many concessions to the contesting parties. The Government put in place some political, judiciary and educational measures to resolve the problem. However, the negotiations resulted in a stale mate. Following that, civil disobedience intensified in the two regions after some leaders of the Consortium were arrested and jailed by the Government. Other leaders who succeeded to smuggle out of the country joined a host of Anglophones from the diaspora and they began organizing activities from foreign countries. A great proportion of those populations did not adhere to the new turn of events whereby some Anglophone leaders living abroad began to fight for secession and independence of the two Anglophone regions.

When the open conflict broke out in November 2016, and all through the first phase of the crisis, there were apparently two separate camps: the Cameroon Government and the Anglophone people. The position of some Anglophones regarding the future of the two English-speaking regions has radicalized, going from request for dialog to outright rejection of any form of discussion with the Cameroon Government. The Anglophone hardliners claimed that secession was the only means of bringing a sustainable and lasting solution to the Anglophone problem. From the request for decentralization, or federalism, the only plea and request of those leaders was separation (secession), without which things would not come back to normalcy in the Anglophone regions. Following this, there has been only timid resumption of schools in those regions. The unbending positions of the secessionists has provided the opportunity room for the emergence and manifestation of a group online activists Anglophones who openly advocate for non-secession, dialog and peaceful resolution of the Anglophone problem under the Cameroonian nationality.

\subsection{Historical Background and Literature Review}

Cameroon is officially a bilingual and bicultural nation which was established on 1st October 1961 after the reunification of the two Cameroons: the French Eastern Cameroon and the British (Southern) Cameroons. This political act came as a result of a referendum in the Southern Cameroons to determine whether the British Cameroons which had been administered by Great Britain under Nigeria under the League of Nations and the United Nations Organization trusteeship. Before then, the two territories had been one German territory.

On Saturday 12 July 1884, Cameroon became a German protectorate whose colonial rule went with mixed blessings until Germany lost the First World War in 1914. As a result, Germany's former colonies were placed under United Nation Organization. Cameroon was shared between Britain and France in the ratio one quarter respectively. French Cameroon (the three quarters) became independent on 1st January 1960. The British Cameroons were due to obtain their independence in 1961, alongside Nigeria. Resolution 1352 (XIV) of the UN General Assembly of 16th October 1959 concerning the Plebiscite set the rules of the game. In this respect, the conditions of their independence were set by the United Nations and the British Government. They had to choose to join either the French Cameroon, or remain as an integral part of Nigeria under 
which they had been administered until that time. While the Northern Cameroons opted through a plebiscite to join Nigeria, the Southern Cameroons chose to reunite with their Francophone "brothers'. According to Ebong Njume (P.7) the British neglected their part of Cameroon as it was annexed to Nigeria and governed it like a Nigerian Province. This poor governance and treatment of Cameroonians as Njume notes "provided pro-reunification campaign ammunition for Foncha's KNDP in the lead-up to the 1961 plebiscite. (Ebong Njume n.d P.7)"

It should also be noted that there was no consensus among Anglophone leaders about reunification with the French Cameroon in 1961 ((Konings and Nyamnjoh, 2000; Nfi, 2014; Anye, 2008; Konings, 2005; Fonchingong, 1998). In fact, abundant literature shows that a number of Anglophone Cameroonians have always wanted to secede from Cameroon -since 1972--. It appears that the United Nations and Great Britain that was exercising tutelage on the territory (Konings and Nyamnjoh, 2000) did not admit the third option: establishing their own independent state. Since then, some movements like the Southern Cameroons National Congress (SCNC) have always publicly advocated for secession, and have always attempted to hoist a flag other that the Cameroonian official flag on October 1st every year. However, the movement has never been gained popular approval or been expressed so vehemently. The Anglophone dream of making a peaceful and harmonious union with their Francophone brothers of the other side of the Mungo turned out to be a nightmare, as many Anglophone activists' lament. Ebong Njume (n.d.) comments that

"...having been disappointed by the conditions of their annexation to Nigeria for decades, Anglophones are also disappointed by the dismal outcome to date of the more than 50 years of their union with Francophone Cameroon - a whole CENTURY thus lost in the chase of illusions" (Ebong Njume n.d P.7).

The Anglophone communities have expressed their dissatisfaction about the union at several occasions, some of which were institutionalized. This is the case of the All-Anglophone Conferences (AAC 1 and AAC 2) which were held in 1993 and in 1994. The Anglophones complain that their recommendations have received a deaf ear from the Cameroonian Government. Since November 2016, this disillusion of the Anglophones has been expressed vehemently throughout the two regions through civil disobedience, arson, mass protest, as well as armed conflict to obtain secession. The social media have played a great role in mass mobilisation as they have been the key means through which the secessionists (in and out of the country) have propagated their separatist ideology.

\subsection{Research Problem}

Since the Anglophone crisis is on-going, there is no study that has been carried out so far on how computer-mediated ideological discourse is used to challenge or reproduce the Cameroonian nationality or particularly how the Anglophone community defend Anglophone nationalism while repudiating their Cameroonian collective Identity.

Before the advent of Computer Mediated Communication (CMC) resulting in the emergence of social media, most revolutions and insurgencies have been instrumentalised either directly by orators, or via mainstream media (flyers, Press, Radio and TV). Recently however, the impact of social media has been felt in mass mobilisation for nationalist causes in general and secessionist inclination in particular (Qiyao Yin, 2016, Chiluwa, 2012; Christensen, 2011).

Till date, there are very few researches dealing with the discourse analysis of nationalist issues as they are captured by the social media. Some discourse analysts (Wodak et al, 1999, Cordor, 2000, 
Edensor, 2004, cited by Qiyao Yin 2016, Shey, 2011) have analysed how people make sense of their national identities in routine activities like shopping, driving and watching football. Other researches (Qiyao Yin 2016, Chiluwa, 2012, Christensen, 2011) have looked at how socio-political crisis have been treated by the mainstream media and the social media.

\subsection{Research questions}

On the backdrop of the ongoing Anglophone socio-political crisis in Cameroon, how do the Anglophone activists and nonand non-activists use the social media to reproduce the panCameroonian nationality while rejecting Anglophone separatism on the one hand, and how is Anglophone nationalism promoted to the detriment of the Cameroonian collective identity? In other words, how is the Cameroonian identity challenged or reproduced in Anglophones' discussion about the Anglophone Regions' status on Facebook? Thus, this study is interested in answering the following questions.

1. How are different social agents represented in the Facebook posts and threads of the two antagonistic groups (polarised positions)?

2. What are the discursive means through which pro-secession Anglophones challenge and repudiate the Cameroonian identity?

3. What are the discursive means through which other pro-union Anglophones reject Anglophone nationalism and assert their Cameroonian nationality?

\section{Theoretical Framework and Literature Review}

In the current study, Critical Discourse Analysis (CDA) (Wodak 2001) is used as the methodological and theoretical approach. CDA derives from Discourse Analysis (D.A.), which provides the opportunity to unite sociologists, linguists and the specialists of other social sciences around the question of language, its social determination and its potential power on society (P. Charaudeau \& D. Maingueneau 2002). Therefore, many scholars agreed that discourse analysis deals with the study of language that focuses on the interpretation of texts (McCarthy, 1991; Schiffin, Tanner \& Hamilton, 2001; Wetherell, Talor \& Yates, 2001; Tonkiss, 2012). The object of study in DA is discourse which is made up of texts, which could be anything including "written texts, spoken words, pictures, videos, or any other interpretable artifact" (Munir \& Phillips, 2005, p. 1667). However, discourses should not be seen as mere texts, they are "large, historical meaning-structures that shape and 'govern' human interaction" (Farfan \& Holzcheiter, 2011, p. 140). In other words, as claimed by Jäger and Maier (2009, p.37), it is not the "subject who makes the discourses, but the discourses that make the subject".

Relating language and social action, Tonkiss (2012) indicates that, although there are different approaches towards discourse analysis, a common understanding among those approaches is that language is the object of analysis. However, the language in this sense is not only the carrier of information, but also the reflection of social meaning, social identity, and social facts (Qiyao Yin, 2016).

While other sciences study human acts and actions, discourse analysis and CDA analyse any human action and act as performed or constructed by language user in a specific social context, more precisely, as social facts are "manners of acting or thinking, distinguishable through their special characteristic of being capable of exercising a coercive influence on the consciousness of individuals" (Durkheim, 1982, P. 43). 
CDA as a methodological approach takes particular interest in the relationship between language and power and examines power tussle in society as reflected through discourse by looking at how discourse is formed and given power, as a result of how power is used, who uses it and the context within which this usage takes place. As Wodak and Meyer (2008. p.10) note, the foundation institution of the CDA approach is to analyse "opaque as well as transparent structural relationships of dominance, discrimination, power and control as manifested in language" (Wodak and Meyer, 2008 p.10). It is a type of discourse analytical research that primarily studies the way social power abuse, dominance, and inequality are enacted, reproduced, and resisted. Critical discourse analysts, then, take explicit position and want to understand, expose, and ultimately resist social inequality. As a research method, CDA thus centres on understanding the ideological machinations of discourse, and aims to produce a critique of how discourse operates to effect certain agendas. CDA studies social movement as they are instrumentalised by language through discourse. Weber (1992, p.13) and Simmel (1971, p. 23-35) regarded language as "a reciprocal action in which conversation (and communication by extension) fuels, strengthens and spreads out representations orienting human activity. Thus, what is usually called society has to be seen as the product of this action". Fairclough (2000, p.156 commented on the connection between language, discourse and social practice saying that "There is no social practice whose activity excludes language - language is always part of the action. Because social action involves communication, hence language and other types of semiotic activity. (...) So, discourses are an inherent part of all social practices." In the same light, Bakhtin (1986) argued that "verbal discourse is a social phenomenon" constituted by speakers within a concrete situation with a very specific purpose.

CDA approach has been utilized to study social phenomena in such fields as politics (Chiluwa, 2012; Christensen, 2011). CDA sees discourse as a social act aimed at transforming power relation and social order. It centres on politics. Discourse is central in ideology construction, modelling, reproduction, and /or challenging. Lister (2009) describes discourse as systems of language that constitute certain social behaviours. It could be argued that discourse analysis usually tries to figure out the social meaning and social realities through the study of texts (Tonkiss, 2012).

Since this study is about a socio-political crisis, CDA seems to be the most appropriate methodological approach. We follow the discourse-historical approach (Wodak \& Meyer 2009a) as the relevance of the antagonists' discourse can be fully apprehended without the understanding of the historical background. Moreover, it permits a more interdisciplinary, sociolinguistic perspective to the data analysis.

It is one of the two main approaches to CDA that have developed since the 1960s. In the approach associated with Fairclough $(2000,2003)$ the analytical framework centres on a discursive event, an instance of language use, analysed not only as text, but also as discursive and social practice.

\subsection{Nationalism as a political ideology}

Nationalism derives from the word nation, which is a concept different from state. According to Stothart (2014), 'nation' is a sociological term that refers to a group of people who have a sense of connection with each other. This connection can be on the basis of language, ethnicity, culture or geographic proximity. On the other hand, 'State' is a political term that includes four elements; people, territory, government and sovereignty. In essence, the term 'nation' symbolises the social unity of a people, while the term 'state' politicises that union. Qiyao Yin (2016:5) cites Gellner (2008: 1132) who comments that nationalism is usually used as a "process of the formation of nations," a "national sentiment" of "belonging to a nation", a "symbolic language" of "meanings 
attached to the nation", a "movement with political goals for the attainment or maintenance of the status of a nation", and an "ideology" of the "nation" to seek its own "autonomy, unity, and identity"

According to Qiyao Yin (2016), there are so far three perspectives in the study of nationalism; the modernist approach, the primordialist approach, and the ethnosymbolist approach. The modernist approach advanced by Ernest Gellner and Benedict Anderson regards nation as an imagined community rather than a natural entity. In their view, nationalism is a modern phenomenon and nation is a modern product that emerged with the French Revolution and industrialisation. Gellner (2008), points out that nationalism is a theory that justifies the legitimacy of the ruling party. It promotes the formation of a common community in which people share a common culture, history, language, religion and territory. In this sense, nationalism is an invention of the modern intellectual elites whose 'version of nationalism provided people a sense of belonging by imagining a common community in which small local communities could be grouped together' (Qiyao Yin 2016, p.11). Still in the same vein, Benedict Anderson (2006) claims that nationalism emerged as a theory, or an ideology for the dominating social groups to legitimise their power and behaviour in a given society, neglecting the fact that nationalism could also be claimed by smaller communities that did not have their own nation-state (Qiyao Yin (2016, p.12).

Unlike the modernist approach, the primordialist approach represented by Edward Shils and Clifford Geertz understands nation as a natural product of history and nationality as a natural part of human beings. This view insists that nations have existed since time immemorial, and always predate their final form. A nation tends to manifest when the appropriate leader, or circumstance are re-awaken. This organic view of nationalism holds that peoples are naturally divided into nations (Jacquin, n.d, p. 35).

The third approach, ethnosymbolism represented by Anthony D. Smith (1991) brings a compromise between the first two approaches. According to this view, nationalism is a cultural ideology that is based on the cultural similarities such as the shared historical memories and traditions, but could also be modified politically by the authorities into a political ideology that suits their political goal. It further argues that although the notion of nation emerged in modern times, nations have an ethnic origin. In this context, ethnicity is used to distinguish one nation from another (Qiyao Yin (2016).

Commenting on Smith (1991, p.15 and 2002, p.15) definitions of nationalism, Qiyao Yin (2016, p.14) summarises those definitions, maintaining that a nation has three fundamental elements, namely (a) the existence of a territory, (b) the existence of a people who shares common myths and historic memories and (c) the same public culture and legal, political, economic system. These three approaches to the nationalism paradigm share the view that people within the same nation whether naturally, politically or culturally formed "all share the same national identity and people acknowledge their shared national identity with others within the same nation" (Qiyao Yin 2016, p.15).

In the same vein, Michael Billig (1995) brought the concept of banal nationalism into scholarship and explained that in established nations, people reproduce national identity through mundane activities like singing the national anthem and hoisting the national flag in public buildings and schools. Billig (1995) suggests that nationalism should be studied on a day-to-day basis as it is either connected with national independence or linked to extremists. 
Social media role has been felt in socio-political changes recently. They have been found to be an enduring force for the successful mobilisation of bottom-up, grassroots movement and leaderless collective actions (Bardici, 2012). As their scope keeps developing, and their role in social transformation and political processes gets more and more significant, new forms of expressions that spur wider civic participation are established. The Arab springs have revealed the potential of new social media in bringing new dynamics into civic engagement and public mobilization as they were used as means to ignite and maintain insurgency and political transformation (Bardici, 2012). During the Egyptian revolution, through text on Facebook, people engaged in discourse, arranged protests and cause the government such concern that it "shut down the Internet and cell phone networks across the country" (Nelson 2012, p. 21 in Albert et Salaam 2013, P.3). They were instrumental in bringing about political change by facilitating its underlying processes through promoting civic engagement, triggering public mobilization, enabling citizen journalism, stimulating civil society, promoting a sense of community among marginalized group members, creating less confined political spaces, and publicizing causes to gain support from the global community (Khamis \& Vaughn, 2011; Khamis, 2011; Eltanatawy \& Wiest, 2011 in Albert and Salam, 2013)

The arena where the Anglophone crisis has been made more visible was the social media and networks. Although there was not real restriction of access to the mainstream media, most of the leaders of the secessionist wing of the Anglophone crisis did not (do not) reside in Cameroon. Dayton (2015) notes that due to the fact that identities and grievances are sometimes sensitive and does not benefit from support from the governing leaders who are criticised, separatists ( within the territorial confines) use communications technologies and transnational networks to organize political action and attract support from diaspora groups and foreign sympathizers (p. 136). In the case of Cameroon, the activists were in their majority based outside the Cameroonian territory. These separatists in the diaspora use social media to organize political action and attract support but more specifically to communicate with the Anglophone people living within the two Anglophone regions. During this sensitive period in Cameroon, Facebook afforded the activists as well as common users both private and public communication with peers and target population within their network and living within the confines of the Anglophone area of Cameroon and beyond. Also given the delicate nature of the issue (secession) the protagonists (proponents) would not have had the opportunity to freely express their point of view on the mainstream media (TV, Radio or press). Despite freedom of the press in Cameroon, there are topics that cannot be addressed without some censorship. Furthermore, the leaders of the secession knew that they were leading an illegal movement, and so do all the defenders of that view. Facebook was therefore the only place where they did express their views. Moreover, these communications platforms revealed very powerful means of communication, because the government could not control or filter everything that was being said there. This is what explains the decision of the Government to shut down the internet in the two regions for 3 months (from January to April 2017).

\section{Methodology}

The data for the study is a selection of text-based posts (messages and conversations) on Facebook written by Anglophone Cameroonians. Two main Facebook pages have been used as samples as they represent the two adversaries and polarised positions regarding the Anglophone crises. One of them, named 'Cameroon journal' with the URL: 'https: //fr-fr.facebook.com/SCACUF' is webmastered by Southern Cameroons Ambazonia Consortium United Front (SCACUF), a separatist 
group. The other group, a pro-unionist, is called English Cameroon for a United Cameroon (EC4UC) with URL: 'https://www.facebook.com/OneCameroonPeaceUnityCommonsense'. Messages, discussions and posts on those Facebook pages are made public mainly by opinion leaders, politicians and social activists.

\subsection{Methods of Data Analysis}

This study attempted to go beyond linguistic elements analysis to include a systematic construction of the historical and political, sociological and/or psychological dimension in the analysis and interpretation of specific texts/discourse. To analyse how Cameroon nationalism is challenged or reproduced in people's discussion about the status of the Anglophone regions of Cameroon on Facebook, the trolls and comments posted by either of the antagonistic groups were selected as the researching texts. The data consist of thousands of posts words addressing current national issues. Obviously, all the posts were in English. And for the convenience of analysis, all the comments analysed were printed as hardcopy.

While sociological research can help to perceive banal nationalism more effectively, discourse analysis captures people's expression of their attitude towards their national identity. In other words, the research seeks to study how Anglophone Cameroonians verbalise in discourse banal nationalism as this would have been otherwise studied from a socio-political perspective by looking at concrete everyday activities. This research will firmly rely on this assumption to justify that the pan-Cameroonian identity is challenged by Anglophone separatists but reproduced by their unionist counterparts. Moreover, it is also expected in this research that the two antagonistic groups of Facebook users show different views concerning what constitutes a nation and how they feel about their pan-Cameroonian and Anglophone identities.

\section{Data Analysis}

The ongoing Anglophone crisis has led to polarised positions amongst the very Anglophone who were unanimous about the existence of an Anglophone problem in Cameroon. The polarised stances of the two antagonistic groups are summarised in the following post that was found on the EC4UC page.

There are only two truly contesting visions for the two regions: Either asserts your self-declared right to leave by taking up arms or remain and constructively contribute to improve the country.

The "use arms to leave" camp is most accurately represented Dr. Ebenezar Akwanga. We respect his principled secessionist position but absolutely reject it, partly because of our aversion to civil war and partly because of our desire to preserve our cherished heritage.

The "remain and improve" camp is more actively represented in this forum through the voice of Ben Akih, so the true dilemma might be called the Akwanga-Akih crossroads. (EC4UC1)

The above statement clearly states the opinions and polarized positions of the Anglophone activists. There are, as it states, the secessionists or the 'use arms to leave', and the unionists or the 'remain and improve'.

\subsection{The Separatists' Discourse (Assertion, Promotion and Defence of Anglophone Nationalism)}

The rhetoric of Anglophone nationalism is characterised by a discourse rejecting the Cameroonian nationality and defending Anglophone identity as separate from the Cameroonian identity which is 
associated to French and domination. A number of new "old" terms and names are used to refer to the North West (NW) and South West (SW) regions (hence NWSW), the Anglophone Community, the country Cameroon, the Anglophone community, the insurgency and the secession leaders.

The reunification of the two Cameroons in 1961 was not consensual. We have noted above that there has always been, although very small and sometimes marginal, a separatist group among the Anglophone community in Cameroon. What is puzzling at the moment is why and how the issue has come up this time with a somewhat ugly and violent face. The separatists' discourse asserts Anglophone nationalism while challenging and repudiating the pan-Cameroonian national identity. The discourse therefore makes a clear opposition between Cameroon and Ambazonia (Southern Cameroons), the former being labelled as an occupation force to be expelled from the latter, an independent and distinct nation.

Many people (both Francophone and Anglophone Cameroonians) have just begun to hear and understand the meaning behind some expressions used to refer to the Anglophone Communities. The Anglophone separatists (secessionists) have decreed that they have their own state which is called Ambazonia, Ambaland or Southern Cameroons. However, these designations seem not to have the same connotation in their mind.

\subsubsection{Proclaiming Ambazonia, Ambazonian, Ambaland, Southern Cameroon (SC) as the new homeland.}

From November 2016, Cameroonians have become acquainted with some new terms and names such as Ambazonia, Ambaland, Ambazonians, Amba time as they are used repeatedly and insistently by the separatists. Separatists refer to the two administrative regions of Cameroon, North West and South West Regions (Anglophone or English-speaking regions) as 'Ambazonia', 'Ambaland', or 'Federal Republic of Ambazonia', and Anglophone people as 'Ambazonians', a derivative from "Amba". The following posts (1-5) illustrate this.

Post 1: Amba Nation SCACUF what are you doing? AMBAZONIA PEOPLE have you now seen that dr ebenezer akwanga is there to give us the truth because he really love his people.

Post 2: Nangin Ndum Thanks for the information am say u are the strong ambazonian

Post 3: Dave Anye This is just one of refined brains of the AmbaLand.

Ernie Rnie - 6:17 Ambazonia is a people and not individuals - we are not short of leaders in Ambazonia.

Post 4: Christoph Messner • 3:27 Good setting of priorities and motivations, Commander Ayaba! God bless you! Long live Ambazonia!

Post 5: Obabs Akam God forbid that we get stocked. Freedom lovers, Ambas men and women, Let's do the Obama thing, 5 dollars every now and then. It is sacrifce, let' do it

The common Cameroonian had not heard those appellations until the year 2017. It took some historical accounts by some former officials to enlighten the people. According to Abouem A Tchoyi citing Delancey et al (2010), the term Ambazonia came into use in the 1990s as a name for a proposed independent country within the boundaries of the old Southern Cameroons. In fact, SCNC proclaimed independence for Ambazonia. For the first time on 30 December 1999. It was the culmination of a series of actions taken by the Anglophone community since 1984. In fact, The Anglophone nationalist activism was reinforced, following the changing of the name of the country from la République Unie du Cameroon (the United Republic of Cameroon) to the Republic of Cameroon (la République du Cameroon) in 1984. This move was perceived by the Anglophone 
community as the final action to assimilate the Anglophones by their Francophone counterpart. since the Anglophones consider themselves as a distinct people with a distinct identity who willingly chose to unite to their Francophone brothers.

For the Anglophone extremists calling themselves Ambazonia is a way of reasserting that distinct identity. Abouem A Tchoyi recounts that the name dates back to 1492. When the Portuguese explorers anchored on the Limbe bay after the Wouri River on the day of Saint Ambroise they called it «Ambass Bahia », Ambroise Bay. Under the influence of English, the name became « Ambass Bay ». At the time of reunification, some people wanted to call the territory Ambazonia, but due to non-agreement or lack of consensus, Southern Cameroon was preferred. The fact that some separatists now call the English-speaking regions Ambazonia speaks volume on this burning desire to 'restore' their lost identity.

\subsubsection{Referring to Anglophones as Ambazonians and Southern Cameroonians.}

One of the discourse strategies of the secessionists is to systematically and recurrently refer to the NW and SW Regions (Anglophone or English-speaking regions) as Southern Cameroons (SC) and the natives of those regions as Southern Cameroonians (Scians). Ambazonia(n) and SC(ians) are sometimes used interchangeably. This is illustrated by the following posts 6-9:

Post 6 Alicia Ambaz Ambaz The teachers and all SCians must step out now. Its now or never.

Post 7 Moise Tanyi (....) Childish behavior as exhibited can never be tolerated by southern Cameroonians....

Post 8 Frank Chesco Why don't we ask Southern Cameroonians in the US navy to stand and fight for the people of Ambazonia. They are thousands of them

Post 9 T-boy Tebuk S.D.F. Party from 'Beacon of Hope' to Liability for Southern Cameroonians Are you as an individual becoming a Liability to SC as well?...

By referring to Anglophone Cameroonians as Southern Cameroons, the separatists want to return to their former (lost) identity. The expression reminisces the pre-reunification period. The name Southern Cameroons refers to the national identity of the Anglophone People before reunification. Referring to the NW and SW regions as such, 57 years after reunification reflects a state of mind of the secessionists regarding the reunification pact.

It must be recalled that in 1961 during the referendum, there were two separate parts of the former German Cameroon that had been administered by the British under Nigeria. There were the Southern Cameroons and the Northern Cameroons, but the majority of the Northern Cameroons' citizens chose to join Nigeria, while the Southern Cameroons voted for reunification with their Francophone brothers of French Cameroon. Some activists reject the validity of the 1961 reunification deal, calling it 'the 1961 mafia'

\subsubsection{Use of French 'La République du Cameroon (LRC), or La republic (LR)' instead of the Republic of Cameroon.}

The other discursive strategies of the secessionists in their move to challenge or repudiate the Cameroonian identity or nationality consist in referring to Cameroon exclusively using the French expression: La République du Cameroun (LRC) including other associate variants like La Républic (que) (LR). This code switching and mixing translates the fact that this cross-section of the Anglophone Cameroonians do not want to identity with Cameroon anymore. By this linguistic 
choice, they want to emphasize that there is a clear divide between the English and Frenchspeaking Cameroons. The following posts illustrate this:

Post 10: Southern Cameroons Ambazonia Consortium United Front-SCACUF La République will block it and arrest anybody who is in charge of such an arrangement

Post 11: Eva Dawoh Who is a hypocrite here, The Republic of Cameroon that knows the 1961 mafia and stick to it or those who have come to uncover the mafia and want to make things straight? It will pay you if you stop addressing people fighting for their rights TERRORISTS.

Post 12: Molars Molars This is not important...

Rather, it looks like la republic trying to hack this page and spy on southern Cameroonians

This discourse strategy also involves expressing their infringing support for civil disobedience and arson as expressed in the following post 13. In this perspective, the Government of Cameroon and the military forces are seen by separatists as occupational forces the must be expelled from their country.

Post 13: Rolux Ndapo - 6:20 Let's intensify ghost towns and schools boycot, burning of la republique's structures in our territory and completely push out all la republique's colonial administrators from our country

Other discursive strategies include: labelling Cameroon as an enemy country and cursing the Cameroonian military forces as they are considered as forces of occupation of 'the republic of Cameroon'

Post 14 Mbuh Malcom God will punish la Republique du Cameroun

Nchaw Dewa We want to use only our police force to combat the terrorists LA Republic.

Furthermore, the ongoing insurgency is considered by the activists for separation as a 'Revolution or a Struggle for Independence, Freedom from Cameroon, and restoration of Anglophone identity. This attitude is manifested through overt support for the social uprising as well as an assignment of a positive connotation to illegal insurrectional activities. In those cases, the fight for independence is seen as a positive action.

The 'Restoration' of the independence of the British southern Cameroons is another expression used to justify the insurgency. Many pro-secessionists see their struggle as a way of restoring their lost identity and territory. As such since it is believed by them that Britain and the UN did not give them the choice to stand independently, it is time for restoration.

Post 15: Langwan Lesley Yes that is the issue it will be difficult though but total independence is achievable and our ultimate stance federation had failed and still will fail with the type of government we have in Cameroon. we need to be wise see the treatment our pple got and are still getting the government of Cameroon is not as friendly as the federalist think. Wona shine eye oo . Total independence is the key we start from there

Post 16 : Ngum Ta ... Anything humanly possible to do I will do for the purpose of our Restoration of INDEPENDENCE.

Another remarkable linguistic construction of the Anglophone nationalism is the labelling and reference of the on-going insurgency. Pro-separatists call it a struggle for independence, since they consider themselves as a separate nation from the Republic of Cameroon. In other instance, after the 1st October 2017, declared as their Independence Day, the separatists began considering the NW and SW regions as independent territories from the Republic of Cameroon. The separatists' commitment to their cause and the illusion that they are independent pushed them to call Sisiky 
Ayuk Tabe their president. Post 17 shows that the activists consider Ayuk Tabe as their president since he is acting as the interim Government president. Activists therefore consider his arrest as a kidnapping and deportation.

Post 17: Ambalander Nzille activation of motions of support to h.e. Sisiku Julius Ayuk Tabe \& an urgent call to the u.n.o. \& the international community to intervene in the british southern cameroons to prevent genocide (block by block: county by county, community by community, ...See more

Post 18: mbalander Nzille Oh, what a humble and wise president God has given us! You are the Moses of Ambazonians. We are behind you your excellency.

Post 19: John Matute - 6:25@PR_Paul_Biya has kidnapped the president of Ambazonia @PR_Ayuk_J_Tabe \& his carbinet members.Dialogue between \#Cameroon \& \#Ambazonia will be to discuss terms of separation. Anything short of that is waste of time \& resources.It's over \#Ambazonia \#FreeAllArrested \#FreeAmbazonia

Other activists have even considered the declaration of independence that was pronounced on $1 \mathrm{st}$ October 2017 as legally valid, thereby considering the Anglophone regions as already independent from the Republic of Cameroon. As a result, they request the liberation of their territory by LRC. As they begin to consider that the NW and SW are separated from Cameroon, activists also assert their resolve to go into arm conflict in order to liberate their 'independent country'. In that respect, they praise the military activities being perpetrated by armed militia called Ambazonian Defence Forces (ADF). Post 20-22 illustrate this ideology.

Post 20: Nchaw Dewa Mr President I have a great idea to make sure we have some supporters as you said. We can get weapons in less than $48 \mathrm{hrs}$, please contact me for more information on this. We are ready to fight for freedom. Please contact me.

Post 21: "The ADF is doing a commendable job on the ground. That is the commencement of exactly what will free our homeland. Other Self Defense outfits MUST join forces with the ADF."

Post 22: Pascal Kiki • 0:00 SUPPORT THE PUSH OUT! Now is the time to let LRC know that they must leave our territory!

\subsection{The Unionists' Discourse}

While the purpose of the unionists' page is to promote peace and union of Cameroon and to combat the ideas of their separatists' peers, both pro and anti-unionists do post on the conversation threads. This section provides an analysis of those posts that shun secessionists' views and defend the unity of Cameroon. They reject the idea of secession, call for dialog with the government, and maintain that Cameroon is their country etc.

Rejection of the Ambazonian identity and Anglophone nationalism

The following post (23) clearly expresses this pro-unionist stance as it states:

Post 23: In NW/SW, we are Cameroonians, not Ambazonians; we identify with Africa, not with America, etc. As proud Cameroonians, we reject with the last bit of energy any war by Cameroonians against Cameroonians. The way to peace and stability in our regions lies in pressure on the government with the help of our compatriots in the other regions.

We are Cameroonians and we are Africans; we are not Ambazonians and we are not Americans. Even in the days of British Southern Cameroons, our parents and grandparents deemed it an insult to be called a Nigerian. They insisted on being called Cameroonians. This longing to preserve the 
Cameroonian identity is reflected in the names of all their parties, including Endeley's party, none of which used British Southern Cameroons. The identity always included a "Kamerun".

This group of activists always refers to Cameroon and to Cameroonians as their nationality, refuting the idea of Ambazonia as their new state. Another post tries to put it forward that 'Southern and Northern Cameroons have never been countries' but had been ruled under Nigeria as trusted territories. It adds that "those claiming to be 'Ambazombians' will have to live in this United CAMEROON.... If not they can keep their Ambaland in their brainwashed 'egusi"”

The above declaration on the EC4UC translates the stance of the Pro-unionist group of the Anglophone Community regarding their attitude towards the Cameroonian nationality. Unlike the secessionists who avoid using NW, SW. Using the same historical argument as their separatists counterparts, the pro-unionists recall that 'even in the days of British Cameroon, their parents and grandparents insisted on being called Cameroonian rather than Nigerians. The same argument is used in another post which emphasises that the whole story does not start in the 1960, but pretty earlier. This idea is summarised in the following post (24):

Post 24: All of you are talking about 1960. Is it when the history of Cameroon start?. Can any of you tell if there were Anglophone in Cameroon in 1922? We lost some parts of our country because of French and English. As Cameroonian we will never accept separation of our country!

The point being levelled here emphasizes that reunification was just a means of regaining a 'lost part of the country'. Following the above posts, and despite some insulting posts, other unionist activists add that 'Cameroon will never separate' as they prefer peace 'despite the poor governance and greedy leaders'.

\section{Discussions}

The preceding section has permitted us to see that the Anglophone crisis has provoked adversary opinions regarding the identity of the English-Speaking regions of Cameroon. Moreover, there is a polarisation of opinions amongst the Anglophone population regarding the future of the two English-speaking Regions with respect to the Cameroonian nation. In this section, firstly, the question concerning whether Cameroonian nationalism is challenged or reproduced will be answered. One of the most obvious acts by the Anglophone separatists was to refuse to reproduce these acts in the English-speaking regions of Cameroon. And while, this cannot be better captured only in a socio-political research, CDA enables to unveil the separatist discourse that supports real acts.

Billig (1995)'s concept of banal nationalism refers to the reproduction of national identity in daily life while people may not have noticed. Its emphasis is that nationalism in established nations is embedded in people's routine, and attention should be paid to people's daily reproduction of their national identity, or to say, nationhood. In light with the above, this paper opines that Anglophones activists are repudiating or reproducing their pan-Cameroonian identity not only through concrete acts on the field, but also through language use. This entails posing political acts using mere discourse. This corroborates Weber (1992) and Simmel (1971) argument that language is a reciprocal action in which conversation (and communication by extension) fuels, strengthens and spreads out representations orienting human activity.

The data that have been gathered from the two Anglophone antagonistic groups Facebook posts and presented in the previous section show that activists of both sides use language and discourse to pose a political act. CDA was used to analyse how language is used in socio-political arena to 
negotiate socio-political status. On the one hand the pan-Cameroonian national (collective) identity is repudiated and challenged by the separatists of SCACUF while it is defended, asserted and reproduced by pro-unionists on EC4UC. By challenging the Cameroonian identity, the secessionists tend to affirm, defend and promote a new state called Ambazonia, which according to them would constitute their nation. The Unionists oppose this idea, claiming that Cameroon has always been a nation. In fact, a state is different from a nation, as most states are actually made up of many nations. There are actually very few states that are made up of only one nation (Stothart 2014, Dayton 2015). The analysis provided above shows that there is a polarisation of opinion amongst Anglophone activists regarding the Cameroonian identity on the one hand and the Anglophone distinct nationalism on the other hand. While pro-union Anglophone activists insist that what is paramount is the Cameroonian identity that has always prevailed, their pro-separatists counterparts argue that there has always been an Anglophone identity which is distinct from the Francophone (French) identity. Since discourse is a social action, the above discourse by Anglophone strategy in repudiating and challenging the Cameroonian identity and nationalism was manifested in the field (the ground) by civil disobedience as the insurgents trampled on and burnt the Cameroonian flag, and hoisted a new flag representing the Ambazonian nation. On the field, Anglophone resistance has been manifested through civil disobedience, resistance, arson, hoisting of the Ambazonian flag, allegiance to a new president, declaration of imaginary independence, etc.

The separatists discourse strategy consists in verbally repudiating the pan-Cameroonian identity while affirming, asserting and defending Anglophone nationalism. By using SCs, the separatists want to assert their origins and their desire to remain a distinct entity. It is argued by Anye (2008:86) that "the constitution that was produced at Foumban did not take into account the aspirations of the people of Southern Cameroons. By so doing, they are posing a political speech act. Given that secession is strictly a political act defined as the formal act by which a territory and its inhabitants withdraw or separate from an already existing state with the aim of establishing themselves as a distinct, independent and sovereign state. Allen Buchanan remarks, there is 'no positive theory of secession at present'.

By insisting on calling themselves Ambazonians, or Southern Cameroonians, the separatist Anglophones actively use discourse to secede from Cameroon. Even if it is not politically acted because they do not fulfil the felicity conditions, they pose a political act using discourse.

The construction (the construct discourse) of the idea of their independent state is an act of defiance posed by secessionists towards the Cameroonian Government. It is also a utopic act that has justified military activities by the Cameroonian forces of law in the disputed areas, as no state would accept that part of its territory be cut off. That is why Jacquin (n.d.: 16) claims that secession is a rare occurrence and has frequently been interpreted as indicative of the fact that the principle of sovereign territorial integrity prevails over that of national self-determination, and that justice in the international system is therefore subordinate to order. And even the fact that Cameroon is the common nation for Francophone and Anglophone Cameroonians is challenged by Anglophone separatists has not prospered.

The data have shown that separatists persistently and consistently refused to call themselves Cameroonians, but Ambazonians and Southern Cameroonians (Scians). Moreover, they exclude themselves from the Cameroonian collective identity by referring to Cameroon as La République $\mathrm{du}$ Cameroon (LRC). This refusal to be tagged Cameroonians suggests repudiation of the Cameroonian identity which is associated with French identity and Francophonisation. It seems to 
be a way of affirming their rejection for what they have always considered as the assimilation of the Anglophones by their Francophone peers.

The EC4UC group defends the Cameroonian nationality of Anglophones. A pictorial analysis of their Facebook page shows that they use the Cameroonian flag, and the picture of the Cameroonian National football team as their background profile page. Beyond that, the CDA has permitted to show that they assert their belonging to the Cameroonian nationality and reject Anglophone nationality and secession. For them, the Anglophones do not have a distinct identity that could justify separation from their Francophone brothers. They criticise ghost towns, reject arson, and shun the Ambazonian ideology.

The claim of having a separate identity by Anglophones seems to suggest that Cameroon has failed to construct an acceptable national identity that crystallises all the two people.

\section{Conclusion}

The aim of this paper was to analyse Facebook discourse of unity-disunity amongst the Anglophone community of Cameroon in recent years. The Cameroonian nationality has been questioned by her Anglophone citizens following social uproar. The situation of unrest loosened Anglophones freedom of expression, and they used the social media to voice out their comments and their opinion regarding their adherence to a 'One United Cameroon'. Data analysis shows that there is divided opinion amongst Anglophone citizens regarding their attitude towards the panCameroonian identity and nationalism. While one of the groups called SCACUF support secession and civil disobedience, the other group called EC4UC is in support of a unitary state. A further analysis using Billig (1995)'s concept of banal nationalism points to the fact that the first group comments aim at challenging the Cameroonian nationality while the other group's post aim at debunking the secessionist discourse, and thereby reproducing the pan-Cameroonian identity.

This study has revealed that those who call the North West and South West regions of Cameroon Ambazonia, and Southern Cameroons are in fact not simply referring to this pre-reunification formal political and territorial entity but are actually affirming their contest and rejection of the whole unification process which they consider to be an assimilation or francization of the Anglophone community by their Francophone counterparts. On the other hand, those who keep the nomenclature are in fact reproducing the Cameroonian identity.

\section{References}

[1]Albert, C. S., \& Salam, A. F. (2012). Predatory Coercion in Social Media and Protection of Children Online - A Critical Discourse Analysis Approach. International Conference on Information Systems (pp. 1-10).

[2]All Anglophone Congress. (1993). The Buea Declaration, Limbe: Nooremac Press.

[3]Anderson, B. (1991). Imagined Communities: Reflections on the Origin and Spread of Nationalism, New York: Verso.

[4]Anderson, B. R. (2006). Imagined communities: Reflections on the origin and spread of nationalism. London: Verso

[5]Anye, Fru, Emmanuel. (2008). Issues of Minority Rights in the Context of Political Liberalization: The Case of Anglophone Cameroon. PhD Dissertation, School of Social Sciences, Faculty of Arts, University of the Witwatersrand.

[6]Austin J. L. (1962). How to do Things with Words, Oxford: Oxford University Press.

[7]Bakhtin, M. (1929) Marxism and the Philosophy of Language; trans. L. Matejka and I.R. Tutnik (1973), New York: Seminar Press. 
[8]Bakhtin, M. (1986) Speech Genres and Other Late Essays; trans. V.W. McGee, Austin: University of Texas Press.

[9]Bardici, Minavere, Vera. (2012). A Discourse Analysis of the Media Representation of Social Media for Social Change - The Case of Egyptian Revolution and Political Change. MA dissertation 2012 Malmö University, Sweden

[10]Billig, M. (1995). Banal nationalism. Sage Publications Ltd.

[11]Chiluwa, I. (2012). Social media networks and the discourse of resistance: A sociolinguistic CDA of Biafra online discourses. Discourse \& Society, 23(3), 217-244. doi:10.1177/0957926511433478

[12]Christensen, C. (2011). Discourses of Technology and Liberation: State Aid to Net Activists in an Era of "Twitter Revolutions". The Communication Review, 14(3), 233-253. doi:10.1080/10714421.2011.597263

[13]Condor, Susan. (2000). "Pride and Prejudice: Identity Management in English People's Talk About 'This Country'." Discourse and Society, 11 2: 175-204. DOI:10.1177/0957926500011002003

[14]Dayton, Ross. (2015). 'Separatism, Globalization, and the European Union' Vol. 15 No. 1 February 2015 The Jean Monnet/Robert Schuman Paper Series, Published with the support of the European Commission

[15]Delancey Mark .D., Rebecca. Neh Mbuh, and Mark D. Delancey. (2010). Historical Dictionary of the Republic of Cameroon. 4th ed. Historical Dictionaries of Africa, No. 113. The Scarecrow Press, Inc. Lanham, Maryland, Toronto, Plymouth, UK

[16]Durkheim, E., Lukes, S. (Ed.), Halls, W.D. (Trans.). (1982). The rules of sociological method. New York: The Free Press.

[17]Edensor, Tim. (2004). "Automobility and National Identity." Theory, Culture \& Society, 21 4-5: 101-120. DOI:10.1177/0263276404046063

[18]Eltantawy, N \& Wiest, JB (2011), 'Social media in the Egyptian revolution: reconsidering resource mobilization theory',International Journal of Communication5, pp. 1207-1224

[19]Fairclough, N. (1989). Language and Power. London: Longman.

[20]Fairclough, N. (1992). Discourse and Social Change. Cambridge: Polity Press

[21]Fairclough, N. (1995) Critical Discourse Analysis, London: Longman.

[22]Fairclough, N. (1995b). Media Discourse. London: Edward Arnold.

[23]Fairclough, N. (2000). Discourse, social theory and social research: the discourse of welfare reform, Journal of Sociolinguistics 4, pp. 163-195

[24]Fairclough, N. (2003) Analysing Discourse: textual analysis for social research, London: Routledge.

[25]Farfan, J. A. F., \& Holzcheiter, A. (2011). The power of discourse and the discourse of power. In R.

[26]Fonchingong (2013) The quest for autonomy: The case of Anglophone Cameroon African Journal of Political Science and International Relations Vol. 7(5), pp. 224-236, August 2013 ISSN 1996-0832 @2013 Academic Journals

[27]Fonchingong, T.N. (1998). 'Multipartyism and Democratization in Cameroon' Journal of Third World Studies 15(2):119-136

[28]Foucault, M. (1982) The Subject and Power, Critical Inquiry, 8(4), pp.777-795.

[29]Geertz, Clifford. (1973). The Interpretation of Cultures. New York, Free Press,

[30]Gellner, Ernest. (1964) 'Nationalism' in: Thought and Change, Weidefeld and Nicholson, London,.

[31]Gellner, Ernest. (1987).'Nationalism and the two forms of cohesion in complex societies', in: Culture, Identity and Politics, Cambridge University Press, Cambridge,

[32]Gellner, Ernest. (1994).Conditions of Liberty: Civil Society and its Rivals, Hamish Hamilton, London,

[33]Gellner, Ernest. (2008). Nations and nationalism (2nd ed). Cornell University Press.

[34]Gurr, T. R. (2007). Minorities, Nationalists, and Islamists. In C.A. Crocker, F.O. Hampson,\& P. A all, Leashing the Dogs of War: Conflict Management in a Divided World (pp.115-128). Washington D.C.: United States Institute for Peace 
[35]Halliday, M. A. K. (1984). A Short Introduction to Functional Grammar. London: Arnold

[36]Halliday, M.A.K. (forthcoming). Meaning as Choice. In Fontaine, L, Bartlett, T, and O'Grady, G. Systemic Functional Linguistics: Exploring Choice. Cambridge University Press. p1.

[37]Heraclides, Alexis. (1991) The Self-determination of Minorities in International Politics, Frank Cass \& Company Limited, London, 1991, p. 1; von Hippel, Karen, "The Resurgence of Nationalism and Its International Implications,' The Washington Quarterly, Vol. 17, No. 4, Autumn 1994, p. 186.

[38]Hopper, P. (2007). Understanding cultural globalization, Polity Press, Cambridge.

[39]Jacquin, Dominique.(n.d.) Nationalism and Secession in the Horn of Africa, A Critique of the Ethnie Interpretation. Thesis submitted for the PhD in International Relations London School of Economies and Political Science University of London

[40]Jäger, Siegfried and Florentine Maier. (2009). "Theoretical and Methodological Aspects of Foucaldian Critical Discourse Analysis and Dispositive Wodak, R., Meyer, M. (eds.) Methods of Critical Discourse Analysis, 34-61. New York: SAGE Publications. (PDF) 'You can say we do not want the junkies and the sex workers. But they are here!': On the spatial exclusion of anti-social behaviour in Bratislava - Nové Mesto. Available from: https://www.researchgate.net/publication/321780166_'You_can_say_-

_we_do_not_want_the_junkies_and_the_sex_workers_But_they_are_here'_On_the_spatial_e xclusion_of_anti-social_behaviour_in_Bratislava_-_Nove_Mesto [accessed Sep 13 2018].

[41]Kaplan, AM \& Haenlein, M. (2010). 'Users of the world, unite! The challenges and opportunities of social media', Business Horizons, vol. 53, no. 1, pp. 59-68.

[42]Khamis, S \& Vaughn K (2011). 'Cyberactivism in the Egyptian revolution: how civic engagement and citizen journalism tilted the balance,' Arab Media and Society, no. 13.

[43]Khamis, S. (2007). 'The role of new Arab satellite channels in fostering intercultural dialogue: can Al Jazeera English bridge the gap?', in Seib P (ed.), New Media and the New Middle East, Palgrave Macmillan, New York, NY, pp. 39-52.

[44]Khamis, S. (2011). 'The transformative Egyptian media landscape: changes, challenges and comparative perspectives', International Journal of Communication 5, pp. 1159-1177.

[45]Konings, Piet, Nyamnjoh, F. (2000). Construction and Deconstruction: Anglophones or Autochthones? The African Anthropologist. Vol 7, $\mathrm{N}^{\circ} 1$

[46]Konings, Piet. (2002). 'University Students' Revolts, Ethnic Militia and Violence during Political Liberalisation in Cameroon", African Studies Review 45, 2: pp. 207-29.

[47]Konings, Piet. (2005). «Anglophone university students and Anglophone nationalist struggles in Cameroon ». In ABBINK, Jon, Van KESSEL, Ineke, Vanguard or Vandals. Youth, Politics and Conflict in Africa, Leiden \& Boston: Brill, 161188.

[48]Konings, Piet. and Nyamnjoh, F. (1997). "The Anglophone Problem in Cameroon" The Journal of Modern African Studies 35, 2: pp. 207-229.

[49]Konings, Piet. and Nyamnjoh, F. (2003). Negotiating an Anglophone Identity: A Study of the Politics of recognition and Representation in Cameroon, Brill NV, Leiden, The Netherlands: (Afrika-Studiecentrum Series). No 1, 2003. 230 pp.

[50]McCarthy, M. (1991). Discourse Analysis for Language Teachers. Cambridge: Cambridge University Press.

[51]Munir, K. \& Phillips, N. (2005). The birth of the 'Kodak moment': Institutional entrepreneurship and the adoption of new technologies. Organization Studies, 26(11), 16651687. (PDF) Sociomateriality and Affect in Institutional Work: Constructing the Identity of Start-Up Entrepreneurs. Available from: https://www.researchgate.net/publication/321442076_Sociomateriality_and_Affect_in_Institu tional_Work_Constructing_the_Identity_of_Start-Up_Entrepreneurs [accessed Sep 13 2018].

[52]Nfi, L. (2014). The Anglophone Cultural Identity in Cameroon 50 years after reunification in International Journal of Advanced Research (2014), Volume 2, Issue 2, 121-129 ISSN 23205407

[53]Njume Ebong, Michael.(n.d.). Anglophone Crisis or the Story of Crossed Colonial Visions. online 
[54]Patrick Charaudeau et Dominique Maingueneau. (2002). Dictionnaire d'Analyse du Discours [Texte intégral] Seuil, 2002, 661 p. Paru dans Études de communication, 26 | 2003

[55]Qiyao Yin. (2016). Everyday nationalism online A case study of the Facebook discussion about the status of Taiwan Master Media Studies: Media, Culture \& Society. Erasmus School of History, Culture and Communication Erasmus University Rotterdam

[56]Schiffrin, D. (1994) Approaches to discourse. Oxford: Blackwell.

[57]Schiffrin, D., Tannen, D., Hamilton, H. E. (2001).The Handbook of Discourse Analysis.Oxford: Blackwell Publishing.

[58]Searle J. R. (1969). Speech Acts, Cambridge: Cambridge University Press.

[59]Shils, Edward. (1957). "Primordial, Personal, Sacred and Civil Ties",: some particular observations on the relationships of sociological research and theory. The British Journal of Sociology, 8(2), 130- 145.

[60]Simmel, Georg. (1971). "The Metropolis and Mental Life", p. 324 in Donald N. Levine (ed) Simmel: On individuality and social forms, Chicago University Press, ISBN 0226757765.

[61]Skey, M. (2011). National belonging and everyday life: The significance of nationhood in an uncertain world. Palgrave Macmillan.

[62]Smith, A. D. (1985). (, 'Ethnie and Nation in the Modem World', Millennium, Vol. 14, No. 2, Summer 1985, pp. 127-142.

[63]Smith, A. D. (1991). National identities. Penguin Books of England.

[64]Smith, A. D. (1994). Ethnic nationalism and the plight of minorities. Journal of Refugee Studies, 7(2/3), 186-198.

[65]Smith, A. D. (2002). When is a nation, Geopolitics, 7(2), 5-32.

[66]Smith, A. D. (2004). Nationalism. In Hawkesworth, M \& Kogan, M. Encyclopaedia of government and politics: 2-volume Set. 1132-1149. Routledge.

[67]Smith, A. D. (2005). The genealogy of nations: an ethnosymbolic approach. In Ichijo, A \& Uselac, G. (Eds.). When is the nation: towards an understanding of theories of nationalism. 94-112.

[68]Smith, A. D. (2009). Ethno-symbolism and nationalism: a cultural approach. Routledge.

[69]Stothart, Wade. (2014). Nation-States, Separatist Movements and Autonomy Arrangements: between war and independence - what options does the nation-state have? http://www.defence.gov.au/adc/publications/publications.html

[70]Tannen, D. \& M. Trester. (2013). Discourse 2.0. Language and new media. Georgetown

[71]University Press: Washington D.C.

[72]Tavernier, Aurélie (2002). «Patrick Charaudeau et Dominique Maingueneau : Dictionnaire d'Analyse du Discours ", Études de communication [En ligne], 25 |2002, mis en ligne le 25 mars 2009, consulté le 13 septembre 2018. URL: http://journals.openedition.org/edc/698

[73]Taylor, S. (2004) Researching Education Policy and Change in 'New Times': Using Critical Discourse Analysis, Journal of Education Policy, 19(4), pp.433-451

[74]Tonkiss, Fran. (2012). Focus groups. In: Seale, C., (ed.) Researching Society and Culture. LSE Cities (3rd). Sage, London, UK. ISBN 9781849207980

[75]van Dijk, T. A. (1993). Elite Discourse and Racism. London: Sage Publications.

[76]van Dijk, T. A. (2000). «Parliamentary Debates». Dins Wodak, R.; van Dijk, T. A. (eds.) (2000) Racism at the Top. Parliamentary Discourses on Ethnic Issues in Six European States. Klagenfurt, Austria: Drava Verlag. 45-78.

[77]van Dijk, T. A. (2006). 'Discourse, context and cognition', Discourse Studies 8(1): 159-77.

[78]van Dijk, T. A. (1998). Ideology : A multi-disciplinary approach, Londres, Sage,

[79]van Dijk, T.A. (2001) 'Multidisciplinary CDA: a plea for diversity', in R. Wodak and M. Meyer (eds) Methods of Critical Discourse Analysis, London: Sage, pp. 95-120.

[80]van Dijk, T.A. (2004) 'Text and Context of Parliamentary Debates', in P. Bayley (ed.) Cross cultural Perspective on Parliamentary Discourse, pp. 339-72. Amsterdam: Benjamins.

[81]van Dilk, T. A. (1997). "What is political discourse analysis?", in: J. Blommaert and C. Bulcaen (Eds.), Political Linguistics, Amsterdam: John Benjamins

[82]Weber Max. (1992). The Protestant Ethic and the Spirit of Capitalism, T. Parsons (trans.), A. Giddens (intro), London: Routledge. 
[83]Wetherell, Margaret \& Taylor, Stephanie \& Yates, Simeon (Eds.). (2001). Discourse as Data: A Guide for Analysis. Sage and The Open University, London and Milton Keynes, 338 pp. 18.99 ISBN 0-7619-7158-0 (paperback)

[84]Wetherell, Margaret \& Taylor, Stephanie \& Yates, Simeon (Eds). (2003). Discourse Theory and Practice: A Reader.

[85]Widinugraha, Dwiyatna. (2016). The Papua Separatist Group and Indonesia in the Age of New Public Diplomacy: A Comparative Analysis of Websites, Facebook Visuals, and Twitter. A dissertation submitted to the Graduate Faculty of North Carolina State University in partial fulfilment of the requirements for the degree of Doctor of Philosophy

[86]Wodak, B. Johnstone, \& P. Kerswill (Eds.), The SAGE handbook of sociolinguistics (pp. 139-152). London, UK: SAGE Publications.

[87]Wodak, R and Fairclough, N. (1997). Critical Discourse Analysis. In: Discourse as Social Interaction. London: Sage Publications.

[88]Wodak, R and Meyer, M (2001). Methods of Critical Discourse Analysis. London: Sage Publications.

[89]Wodak, R. (1996) Disorders of Discourse, Harlow: Longman.

[90]Wodak, R. (2001). 'The discourse-historical approach', in R. Wodak and M. Meyer (eds) Methods of Critical Discourse Analysis. London: Sage, pp. 83-94.

[91]Wodak, R. (2008). 'Discourse studies: important concepts and terms', in R. Wodak and M. Krzyżanowski (eds) Qualitative Discourse Analysis in the Social Sciences, Basingstoke: Palgrave, pp. 1-29.

[92]Wodak, R. de Cillia, R., Reisigl, M., and Liebhart, K. (1999). The Discursive Construction of National identity (A. Hirsch \& R. Mitten, Trans.). Edinburgh: Edinburgh University Press.

[93]Wodak, R., \& Meyer, M. (2008). Critical Discourse Analysis: History, Agenda, Theory, and Methodology. Methods for Critical Discourse Analysis (Second., pp. 1-33). London: Sage.

[94]Wodak, R. and Meyer, M.(Eds) (2009) 2nd ed. Methods of Critical Discourse Analysis. London: Sage.

[95] Wodak, Ruth. (2001). "What CDA is About - A Summary of its History, Important Concepts and its Developments". In Methods of Critical Discourse Analysis, R. Wodak and M. Meyer (eds), 1-13. London, UK: Sage. 